\title{
EHMTI-0150. A controlled study of sleep in cluster headache patients.apo04
}

\author{
M Barloese ${ }^{1 *}$, P Jennum²,$N$ Lund ${ }^{1}$, R Jensen ${ }^{1}$ \\ From 4th European Headache and Migraine Trust International Congress: EHMTIC 2014 \\ Copenhagen, Denmark. 18-21 September 2014
}

\section{Background}

Cluster headache $(\mathrm{CH})$ is a primary headache disorder characterized by notoriously severe attacks of unilateral pain following a chronobiological pattern. There is a close connection with sleep as many attacks occur during the night and a complex hypothalamic involvement has been suggested.

\section{Aim}

To investigate sleep in a large, well-characterized population of $\mathrm{CH}$-patients and compare our findings to those in healthy controls.

\section{Methods}

We performed polysomnography (PSG) for two nights in $40 \mathrm{CH}$ patients during active bout and for one night in 25 age, sex and BMI-matched controls on an in-hospital basis. Clinical headache characterization was obtained through a semi-structured interview.

\section{Results}

A total of 99 nights of PSG were analyzed. Our main finding was a reduced percentage of REM-sleep $(\mathrm{P}<$ $0.01)$, longer REM-latency $(\mathrm{P}<0.01)$ and fewer arousals $(\mathrm{P}<0.01)$ in $\mathrm{CH}$ patients. There was no difference in the prevalence of sleep apnea between patients (38\%) and our matched controls (32\%) although numerically patients had a higher mean apnea-hypopnea index (10.75 vs. 4.93). We observed 45 nocturnal $\mathrm{CH}$ attacks but no temporal association with particular sleep stages.

\section{Conclusions}

To date, this is the largest study of sleep in CH. REMsleep is affected in $\mathrm{CH}$ which is in line with our current understanding of $\mathrm{CH}$ and newer studies indicating

${ }^{1}$ Neurology, Danish Headache Center, Glostrup, Denmark

Full list of author information is available at the end of the article hypothalamic involvement in the regulation of this sleep stage. Further, we found fewer arousals in $\mathrm{CH}$-patients as has been demonstrated in other headache disorders. Together, the findings support a central role of the hypothalamus and arousal systems in $\mathrm{CH}$.

No conflict of interest.

\section{Authors' details}

${ }^{1}$ Neurology, Danish Headache Center, Glostrup, Denmark. ${ }^{2}$ Neurology, Danish Center for Sleep Medicine, Glostrup, Denmark.

Published: 18 September 2014

doi:10.1186/1129-2377-15-S1-E13

Cite this article as: Barloese et al:: EHMTI-0150. A controlled study of sleep in cluster headache patients.apo04. The Journal of Headache and Pain 2014 15(Suppl 1):E13.

\section{SpringerOpen $^{\odot}$}

(C) 2014 Barloese et al; licensee Springer. This is an Open Access article distributed under the terms of the Creative Commons Attribution License (http://creativecommons.org/licenses/by/2.0), which permits unrestricted use, distribution, and reproduction in any medium, provided the original work is properly cited.
Submit your manuscript to a SpringerOpen ${ }^{\circ}$ journal and benefit from:

- Convenient online submission

- Rigorous peer review

- Immediate publication on acceptance

- Open access: articles freely available online

- High visibility within the field

- Retaining the copyright to your article

Submit your next manuscript at $>$ springeropen.com 